\title{
UPAYA MENINGKATKAN AKTIFITAS DAN HASIL BELAJAR TENSES SISWA KELAS X SMAN 2 JEMBER MELALUI" HUWO GAME DAN PEER TUTORING
}

\author{
MARIYANA \\ SMA Negeri 2 Jember \\ e-mail: mariyana05@gmail.com
}

\begin{abstract}
ABSTRAK
Penelitian ini bertujuan untuk meningkatkan partisipasi dan aktivitas serta hasil belajar siswa kelas X MIPA 8 SMA Negeri 2 Jember melalui teknik Huwo Game dan Peer Tutoring . Bentuk penelitian ini adalah Penelitian Tindakan Kelas seperti yang dipaparkan oleh Kemmis dan MC Taggart yaitu yang terdiri dari empat komponen yang merupakan siklus mulai dari tahap perencanaan, pelaksanaan tindakan, observasi, refleksi dan revisi . Penelitian ini dibagi menjadi 2 siklus yaitu siklus I dan II dan masing-masing siklus terdiri dari 3 pertemuan. Seluruh data diperoleh melalui observasi, tes dan wawancara. Penerapan Huwo Game dan Peer Tutoring ini dapat meningkatkan partisipasi dan aktivitas siswa dalam pembelajaran yaitu persentase keaktifan siswa mencapai 95,4\%. Dengan teknik ini persentase jumlah siswa yang aktif menjawab pertanyaan guru mencapai $91,7 \%$ dan yang aktif dalam diskusi kelompok mencapai $94,4 \%$ sementara tingkat kehadiran siswa stabil yaitu $100 \%$.Tidak hanya partisipasi dan aktivitas siswa yang meningkat akan tetapi jumlah siswa yang tuntas belajar meningkat sangat signifikan dari sebelum pelaksanaan siklus I sampai pada akhir siklus II yaitu pada pra siklus hanya 17 siswa (47,2 \%), menjadi $28(78 \%)$ setelah siklus I dan menjadi 34 (94\% )setelah siklus II. Dengan penerapan teknik Huwo Game dan Peer Tutoring pada pembelajaran Tenses, hasil belajar siswa mencapai ketuntasan secara klasikal yaitu lebih dari $85 \%$.
\end{abstract}

Info Artikel :

Diterima :

20 Juni 2021

Diperbaiki :

1 Juni 2021

Disetujui :

12 Juli 2021

Kata Kunci:

Hasil Belajar

Tenses, Huwo

Game dan Peer

Tutoring

\section{PENDAHULUAN}

Salah satu kompetensi mata pelajaran Bahasa Inggris yang harus dicapai oleh siswa SMA khususnya siswa kelas $\mathrm{X}$ adalah siswa mampu menyusun teks lisan dan tulis, agak panjang dengan menggunakan struktur teks dan unsur kebahasaan secara akurat dan berterima seperti yang tertulis di dalam Peraturan Menteri Pendidikan dan Kebudayaan Nomor 21 tahun 2016 Tentang Standar Isi Pendidikan Dasar dan Menengah. Kompetensi tersebut terangkum di dalam empat keterampilan berbahasa yang harus dikuasai siswa yaitu membaca (reading), menulis (writing), berbicara (speaking) dan mendengarkan (listening). Untuk menguasai empat keterampilan bahasa tersebut ada elemen-elemen bahasa yang harus dikuasai siswa yaitu tatabahasa (grammar), kosakata (vocabulary), content (isi), dan cara pengucapan ( pronunciation). Seperti yang dikemukakan Widiati dan Cahyono (2006:78) bahwa keberhasilan dalam menguasai ke empat keterampilan bahasa (membaca, mendengarkan, menulis dan berbicara) bergantung pada beberapa unsur-unsur pembentuk bahasa seperti tatabahasa, kosakata dan cara pengucapan.

Tenses merupakan bagian dari tatabahasa Bahasa Inggris dan salah satu komponen berbahasa yang sangat penting dalam Bahasa Inggris. Tak bisa dipungkiri bahwa dengan menguasai tenses siswa tidak hanya mampu menghasilkan kalimat-kalimat bahasa Inggris yang benar akan tetapi mereka juga mampu berkomunikasi dalam Bahasa Inggris secara efektif dan berterima. Ada 5 Jenis tenses yang akan di bahas dalam penelitian ini yaitu : Present Continuous Tense, Simple Present Tense, Simple Past Tense, Present Perfect Tense 
dan Simple Future Tense. Alasan pemilihan materi tersebut adalah karena tenses tersebut banyak ditemui siswa pada saat belajar materi -materi di kelas X. Alasan lain adalah Tenses khususnya Simple Past dan Present Perfect Tense tercantum dalam silabus kelas X pada Kompetensi Dasar 3.6 dan 4.7 kurikulum 2013.

Berdasarkan pengalaman mengajar bahasa Inggris di kelas X SMA Negeri 2 Jember peneliti menemukan fakta bahwa siswa kelas X MIPA 8 tahun pelajaran 2017 - 2018 masih menemui banyak kesulitan dalam memahami tenses. Salah satu indikatornya adalah ketuntasan hasil belajar siswa pada materi tenses yang masih jauh dari batas minimal ketuntasan klasikal yaitu $85 \%$ dari seluruh jumlah siswa dikelas tersebut. Setelah dilakukan wawancara terhadap beberapa siswa peneliti menemukan jawaban bahwa siswa mengalami kesulitan memahami materi tenses karena mereka tidak pernah menemukan materi tersebut dalam bahasa Indonesia yang mana dalam Bahasa Indonesia tidak ada ketentuann bahwa jika keterangan waktu berbeda maka kata kerja yang digunakan akan berbeda pula. Dengan kata lain kapan saja peristiwa itu terjadi maka kata kerja yang digunakan sama. Sementara dalam aturan berbahasa Bahasa Inggris jika tindakan atau peristiwa terjadi dalam waktu yang berbeda maka kata kerja yang digunakan akan berbeda pula. Perubahan-perubahan kata kerja sebagai penyesuaian dengan keterangan waktu itulah yang membuat siswa sulit untuk memahami tenses. Kesulitan tersebut mengakibatkan siswa enggan atau malas mengikuti pembelajaran dengan materi tenses. Motivasi dan antusisme belajar siswa rendah. Rendahnya motivasi dan antusiame siswa dalam proses pembelajaran tenses tersebut juga disebabkan karena proses pembelajaran yang membosankan dan monoton. Sebagian siswa bosan dalam pembelajaran tenses karena metode dan teknik pembelajaran yang digunakan kurang menarik dan tidak menantang. Metode yang digunakan guru selama ini hanya metode ceramah dan mengerjakan soal-soal latihan.

Untuk mengatasi masalah tersebut peneliti berusaha menemukan teknik pembelajaran yang menarik, atraktif serta efektif mengurangi kebosanan siswa dan juga memotivasi siswa untuk antusias dalam pembelajaran tenses. Salah satu teknik pembelajaran yang diterapkan adalah teknik permainan Huwo Game yang dikombinasikan dengan tehnik Peer Tutoring ( tutor sebaya). Huwo Game merupakan akronim dari Hunting Word Game yang merupakan tehnik pembelajaran yang atraktif dan menyenangkan karena siswa dapat belajar sambil bermain. Dengan belajar lewat permainan tidak hanya membuat siswa tertarik untuk berpartisipasi tetapi juga memberi kesempatan yang luas bagi mereka untuk menggunakan bahasa Inggris tanpa dibebani perasaan takut salah .Permainan dan teka-teki merupakan aktivitas yang dapat mendorong siswa tertarik belajar bahasa (Adenan, 1983). Permainan yang dipilih sesuai dengan materi pembelajaran dan disiapkan dengan baik akan membuat siswa semangat dan menikmati proses pembelajarannya. Zuliati ( 2016 : 113 ) menyatakan "Wellprepared games are very useful as they give students a break and at the same time allow students to practice language skills in a joyful situation. Permainan juga membuat siswa merasa tertantang menggunakan bahasa tanpa merasa tertekan dan stres. Dan tanpa dia sadari pula dia menggunakan bahasa dalam konteks yang sebenarnya. Zuliati ( 2016 : 113 ) menegaskan : "Well-chosen games are highly motivating since they are amusing and interesting. At the same time, you may put enough challenge to students so that they will learn to practice the language while having fun and activities. They also employ valuable and practical language in real situation.

Seperti teknik permaianan lainnya, Huwo Game membutuhkan bahan atau materi serta memiliki prosedur atau langkah-langkah dalam pelaksanaannya. Berikut adalah gambaran Huwo Game.

A. Nama permainan : Huwo Game 
B. Materi : tatabahasa khususnya tenses sekaligus memperkaya mosakata karena permainan ini menuntut siswa untuk mampu membentuk kata kerja baik kata kerja bentuk ke-1 ( V1), V2, V3 maupun V-ing dan juga membuat kalimat dengan kata kerja yang sesuai dengan kata keterangan waktu. Permainan ini dapat diterapkan pada semua level kelas khususnya siswa SMP maupun SMA.

C. Durasi : $10-15$ menit

D. Bahan :

1. Kertas sticky note (tiga atau empat warna yang berbeda ) tergantung jumlah group yang bermain dalam sekali putaran.

2. Daftar kata-kata kerja (kira-kira 100 ) kata kerja dengan bentuk kata yang bervariasi ( V1, V2, V3 dan V-ing ). Daftar kata-kata tersebut di tempel di kaca jendela di luar kelas.

3. Form/table isian

\begin{tabular}{|c|c|c|c|c|c|}
\hline No & Verb - 1 & Verb - 2 & Verb - 3 & Verb -ing & Time Signals \\
\hline 1 & write & wrote & written & writing & Yesterday: \\
\hline & & & & & $\begin{array}{l}\text { Wati wrote a } \\
\text { letter } \\
\text { yesterday }\end{array}$ \\
\hline 2 & ...... & ...... & ......... & ... & Tomorrow \\
\hline 3 & 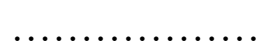 & 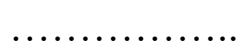 & $\ldots \ldots \ldots \ldots \ldots \ldots$ & $\ldots \ldots \ldots \ldots \ldots$ & Just now \\
\hline
\end{tabular}

\section{Persiapan :}

E. Langkah-langkah

$>$ Siswa membentuk kelompok ( 4-5 siswa ) per kelompok

$>$ Masing-masing kelompok berbagi tugas diantara anggotanya: ada yang bertugas sebagai penulis (sekretaris) yang bertugas mencatat kata-kata kerja yang berhasil di buru oleh temannya yang bertugas sebagai pemburu ( hunter ) .Kata kerja tersebut di tulis pada kolom sesuai dengan bentuk kata kerja yang diperoleh. Ada yang bertugas sebagai hunter. Atau masing-masing tugas bisa dikerjakan secara bergantian.

1. Pelaksanaan :

1) Tim peserta permainan menempati posisi masing-masing, biasanya di bangku bagian depan. Sementara siswa yang tidak sedang bermain bertindak sebagai suporter. Masing-masing tim mendapatkan form dan sticky note untuk menuliskan kalimat yang berhasil dibuat.

2) Ketua tim menuliskan nama-nama anggota tim dan di beri kesempatan untuk berbagi tugas atau mengatur strategi.

3) Setelah semua peserta siap, permainan di mulai. Waktu yang diberikan 10 menit.

4) Para anggota dari masing - masing tim secara bergantian berlari keluar kelas memburu kata-kata kerja yang ada di dalam daftar yang di tempel di jendela kelas bagian luar.

5) Peserta melaporkan kata-kata kerja yang berhasil mereka rekam atau ingat untuk di tuliskan di tabel kata kerja sesuai dengan kolomnya ( V1, V2, V3, dan V-ing ). Dari kata kerja yang berhasil di himpun, peserta membuat kalimat berdasarkan keterangan waktu yang tersedia di dalam tabel dan menuliskan kalimatnya di sticky note dan menempelkan di papan tulis.

6) Permainan berakhir setelah 10 menit .

7) Tahapan selanjutnya adalah checking kalimat yang berhasil ditulis oleh masing-masing tim. Checking dilakukan oleh guru bersama-sama dengan kelas. 
8) Penentuan pemenang adalah tim yang paling banyak menghasilkan kata-kata yang diburu dan membuatnya dalam bentuk kalimat dengan benar.

( created by : Mariyana)

Catatan : Satu kali putaran permainan diikuti oleh 3-4 tim tergantung dari jumlah siswa dalam kelas.

Sedangkan Peer Tutoring atau pembelajaran teman/tutor sebaya adalah pembelajaran di mana siswa sebagai pusat pembelajaran, siswa belajar dari siswa lain yang memiliki status umur, kematangan/harga diri yang tidak jauh berbeda dari dirinya sendiri dengan demikian anak tidak merasa begitu terpaksa untuk menerima ide-ide dan sikap dari "gurunya" yang tidak lain adalah teman sebayanya sendiri. Dalam Peer Tutoring, teman sebaya yang lebih pandai memberikan bantuan belajar kepada teman-teman sekelasnya di sekolah. Bantuan belajar oleh teman sebaya dapat menghilangkan kecanggungan. Hal itu sejalan dengan pernyataan Suherman (2003:277) yang menyatakan bahwa bahasa teman sebaya lebih mudah dipahami, selain itu dengan teman sebaya tidak ada rasa enggan, rendah diri, malu, dan sebagainya, sehingga diharapkan siswa yang kurang paham tidak segan-segan untuk mengungkapkan kesulitan-kesulitan yang dihadapinya.

Banyak kelebihan tehnik Peer Tutoring antara lain: (1) siswa dilatih untuk mandiri, dewasa dan memupuk rasa setia kawanan . Artinya dalam penerapan Peer Tutoring ini, siswa yang dianggap pintar bisa mengajari atau menjadi tutor temannya yang kurang pandai atau ketinggalan; (2) siswa lebih mudah dan bebas dalam menyampaikan masalah yang dihadapi sehingga siswa yang bersangkutan terpacu semangatnya untuk mempelajari materi ajar dengan baik; (3) membuat siswa yang kurang aktif menjadi aktif karena tidak malu lagi untuk bertanya dan mengeluarkan pendapat secara bebas; (3) membantu siswa yang kurang mampu atau kurang cepat menerima pelajaran dari gurunya; (4) tutor maupun yang ditutori samasama diuntungkan, bagi tutor akan mendapat pengalaman, sedang yang ditutori akan lebih kreatif dalam menerima pelajaran. Sementara kelemahannya adalah tidak semua siswa dapat menjelaskan kepada temannya dan tidak semua siswa dapat menjawab pertanyaan temannya. Untuk mengeliminir kelemahan tersebut guru sebagai fasilitator membantu siswa ketika siswa mengalami kesulitan menjawab pertanyaan temannya. Adapun tujuan penelitian ini adalah: (1) untuk meningkatkan aktifitas siswa kelas X MIPA 8 SMAN 2 Jember tahun pelajaran 2017 2018 dalam pembelajaran tenses dengan menerapkan Huwo Game dan Peer Tutoring; ( 2 ) untuk meningkatkan hasil belajar siswa kelas X MIPA 8 SMAN 2 Jember tahun pelajaran 2017 - 2018 pada materi tense.

\section{METODE PENELITIAN}

Penelitian ini merupakan Penelitian Tindakan Kelas ( PTK ) atau Classroom Action Research yaitu suatu penelitian yang yang berakar pada munculnya permasalahan dalam proses pembelajaran. Desain penelitian yang digunakan peneliti mengacu pada model Kemmis dan MC Taggart ( Arikunto, 2010 ) yang terdiri dari 4 komponen yaitu perencanaan ( planning ), tindakan ( action), pengamatan ( observing ) dan refleksi ( reflecting). Subyek penelitian adalah siswa kelas X MIPA 8 SMAN 2 Jember tahun pelajaran 2017 - 2018 yang berjumlah 36 siswa dengan jumlah siswa perempuan 18 dan 18 siswa laki-laki. Penelitian ini dilaksanakan secara kolaboratif dengan seorang guru Bahasa Inggris di sekolah yang sama. Tindakan penelitian dilakukan dalam 2 siklus dimana masing siklus terdiri dari 3 kali pertemuan dengan durasi masing-masing pertemuan adalah 2 x 45 menit. Pada akhir masingmasing siklus diberikan ulangan akhir yaitu pada petemuan ke -3 .

Metode pengumpulan data penelitian ini meliputi : tes tulis, wawancara dan observasi . Tes tulis diberikan untuk mengetahui hasil belajar siswa dan dilakukan pada setiap akhir siklus. Tes tersebut berbentuk objektif : pilihan ganda, melengkapi kalimat rumpang, benar / 
salah dan melengkapi paragraph rumpang. Wawancara dilakukan untuk mengetahui kendalakendala atau kesulitan - kesulitan yang dialami siswa selama mengikuti proses pembelajaran baik sebelum tindakan maupun setelah dilakukan tindakan. Responden wawancara adalah perwakilan siswa dari kelompok belajar cepat ( atas ), kelompok belajar tengah ( normal ) dan kelompok belajar bawah ( lambat). Sementara observasi dilakukan bersamaan dengan proses pembelajaran dengan memberikan ceklis mengenai tingkah laku siswa secara langsung baik kelompok maupun individu. Observasi dilakukan untuk mengetahui tingkat keaktifan siswa dalam proses pembelajaran dengan indikator meliputi : tingkat kehadiran, keaktifan menjawab pertanyaan guru dan keaktifan saat diskusi kelompok. Observasi dilakukan oleh peneliti dan kolaborator .

Siswa dianggap aktif terlibat dalam proses pembelajaran manakala persentase ketiga indikator tersebut telah memenuhi standar yang telah ditetapkan yaitu mencapai $75 \%$ dari jumlah siswa. Sedangkan indikator tingkat pemahaman siswa ditandai dengan ketuntasan hasil belajar siswa pada materi tenses mencapai $85 \%$ dari jumlah siswa yang memperoleh nilai sekurang-kurangnya 76 ( KKM mata pelajaran bahasa Inggris kelas X tahun pelajaran 20172018 di SMA Negeri 2 Jember). Siswa dikatakan tuntas belajar bila mencapai KKM sebesar 76 , dan dikatakan tuntas secara klasikal jika jumlah peserta didik yang tuntas mencapai $85 \%$ dari seluruh jumlah peserta didik dengan rumus sebagai berikut:

$$
\text { Ketuntasanklasikal }=\frac{\sum \text { Siswa.yang.tuntas.belajar }}{\sum \text { Siswa }} \times 100 \%
$$

\section{HASIL DAN PEMBAHASAN}

\section{Hasil Penelitian}

\section{Siklus I pertemuan pertama.}

Pertemuan pertama pada siklus I dilaksanakan pada hari Senin, 2 April 2018. Guru mengawali proses pembelajaran dengan ucapan salam dan mengecek kehadiran siswa. Setelah melakukan apersepsi dan menyampaikan tujuan pembelajaran serta mengajak siswa melakukan literasi dengan menyanyikan lagu daerah ,guru melanjutkan proses pembelajaran dengan melakukan tanya jawab dengan siswa terkait dengan materi tenses. Kegiatan selanjutnya siswa melakukan proses pembelajaran dengan bermain Hunting Word game. Kegiatan inti berlansung selama 70 menit. Sementara guru melaksanakan pembelajaran, kolaborator melakukan observasi kegiatan siswa. Proses pembelajaran ditutup dengan membuat kesimpulan dan melakukan refleksi.

\section{Siklus I pertemuan kedua}

Pertemuan ini dilaksanakan pada hari Senin, 9 April 2018. Guru mengawali proses pembelajaran dengan mengucapkan salam dan mengecek kehadiran siswa. Setelah mereview proses pembelajaran yang telah dilaksanakan dengan permainan hunting word pada pertemuan pertama, selanjutnya guru mereview materi tenses. Kegiatan inti pada pertemuan ini siswa belajar dalam kelompok dengan teknik peer tutoring. Secara berkelompok siswa mengerjakan tugas dengan materi tenses. Kegiatan diskusi dalam kelompok berlangsung 40 menit. Setelah diskusi kelompok dilanjutkan dengan diskusi kelas yang berlangsung 30 menit. Kegiatan pada pertemuan kedua ini diakhiri dengan membuat kesimpulan dan melakukan apersepsi.

\section{Siklus I pertemuan ketiga}

Pertemuan ketiga pada siklus I dilaksanakan pada hari Senin, 16 April 2018. Kegiatan pada pertemuan ini adalah pemberian post test untuk mengukur pemahaman siswa terhadap materi tenses. Hasil pengamatan /observasi selama proses pembelajaran serta post test pada Siklus I dapat dilihat pada table berikut ini: 
Tabel 1 Hasil observasi pra siklus dan siklus I

\begin{tabular}{llllll}
\hline \multirow{2}{*}{ No } & \multirow{2}{*}{ Indikator } & \multicolumn{2}{c}{ Pra Siklus } & \multicolumn{2}{c}{ Siklus I } \\
\cline { 3 - 6 } & Jumlah & $\%$ & Jumlah & $\%$ \\
\hline 1 & $\begin{array}{l}\text { Tingkat kehadiran } \\
\text { Keaktifan menjawab } \\
\text { pertanyaan guru }\end{array}$ & 36 & $100 \%$ & 36 & $100 \%$ \\
3 & $\begin{array}{l}\text { Keaktifan saat diskusi } \\
\text { kelompok }\end{array}$ & 12 & $17 \%$ & 15 & $42 \%$ \\
Rata-rata keaktifan siswa & & $33 \%$ & 18 & $50 \%$ \\
\hline
\end{tabular}

Tabel 2: Hasil post test Pra-Siklus dan Siklus I

\section{Kriteria}

\section{NO Uraian}

Pra-siklus $\quad$ Siklus I

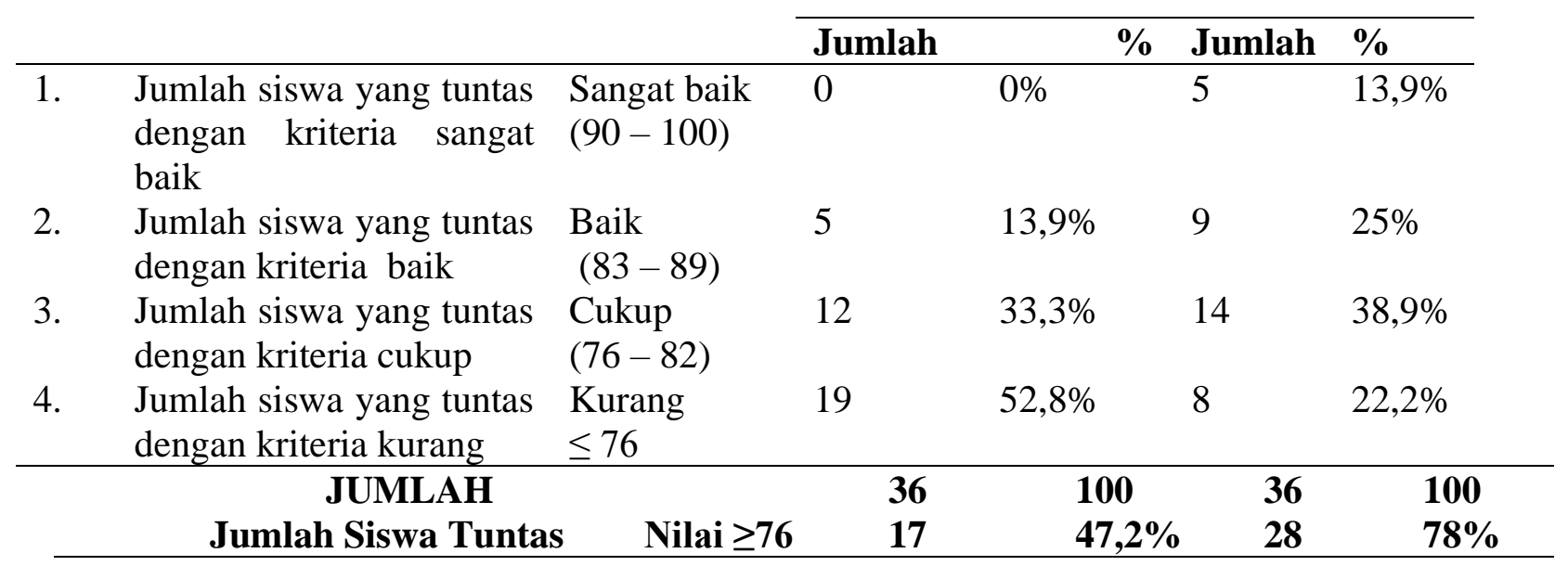

Berdasarkan data pada tabel 1 diketahui bahwa pada siklus I ada kenaikan yang cukup signifikan pada keaktifan siswa baik saat diskusi maupun dalam menjawab pertanyaan guru yaitu jika pada sebelum tindakan siswa yang aktif menjawab pertanyaan guru hanya 6 orang (17\%), pada siklus I meningkat menjadi 15 orang atau $42 \%$ dari jumlah seluruh siswa. Sementara yang aktif dalam berdiskusi meningkat pula dari $12(33 \%)$ siswa sebelum tindakan menjadi $18(50 \%)$ siswa setelah tindakan. Kehadiran siswa stabil yaitu $100 \%$.

Sementara itu, hasil belajar siswa juga mengalami peningkatan setelah pelaksanaan tindakan Siklus I. Hal itu dapat dilihat pada data hasil post test pada tabel 2. Dari data tersebut diketahui bahwa persentase ketuntasan hasil belajar siswa secara klasikal sebelum tindakan siklus I sangat rendah yaitu hanya 47,2 \%. Persentase ini masih sangat jauh dari indikator ketuntasan belajar minimal yaitu 85\%. Setelah menerapkan Huwo Game yang dikombinasikan dengan Peer Tutoring sebagai tehnik pembelajaran tenses, maka pencapaian hasil belajar siswa meningkat yaitu mencapai $78 \%$. Hal itu dapat dilihat pada tabel 2 dimana hasil tes akhir siklus I menunjukkan ada $5(13,9 \%)$ siswa yang tuntas dengan kriteria sangat baik, ada 9 (25 $\%)$ siswa yang tuntas dengan kriteria baik serta jumlah siswa yang tuntas dengan kriteria cukup juga meningkat dari 12(33,3\%) siswa saat sebelum tindakan menjadi 14 (38,9\%) siswa setelah tindakan. Sementara siswa yang tidak tuntas menurun dari $19(52,8 \%)$ siswa sebelum tindakan menjadi hanya $8(22,2 \%)$ siswa setelah tindakan. Meskipun sudah mengalami peningkatan namun hasil ini menunjukkan bahwa secara klasikal siswa belum tuntas belajar, karena siswa yang memperoleh nilai $\geq 76(\mathrm{KKM})$ hanya sebesar 78\% masih belum mencapai presentase ketuntasan yang dikehendaki yaitu $85 \%$. 
Berdasarkan hasil refleksi siklus I diketahui bahwa keaktifan siswa dalam proses pembelajaran serta hasil belajar belum optimal disebabkan oleh beberapa hal antara lain: (1) beberapa siswa masih kurang paham bagaimana permainan dilaksanakan, sehingga jalannya permainan kadang tersendat; (2) kegiatan diskusi kelompok masih belum optimal. Siswa katagori low masih pasif pada saat diskusi dengan kelompoknya. Siswa yang pandai masih ragu-ragu berbagi atau membantu teman dalam kelompoknya yang mengalami kesulitan dalam mengerjakan latihan di Lembar Kerja Siswa. Kondisi ini menyebabkan tingkat pemahaman siswa pada materi yang dipelajari tidak merata dan tidak maksimal sehingga berdampak pada rendahnya paritisipasi siswa dalam menjawab pertanyaan saat diskusi kelas.

\section{Siklus II pertemuan pertama}

Pertemuan pertama siklus ini dilaksanakan pada hari Senin, 23 April 2018. Guru dan kolaborator melaksanakan tindakan pada siklus ini berdasarkan hasil refleksi siklus I. Guru mengawali proses pembelajaran dengan ucapan salam dan melakukan presensi kehadiran siswa. Setelah itu guru meminta siswa untuk melakukan literasi membaca dengan melakukan kegiatan membaca buku berbahasa Inggris. Kegiatan ini berlangsung selama 10 menit. Kegiatan selanjutnya guru mereview kegiatan proses pembelajaran pada siklus I. Guru menjelaskan lebih rinci teknik permainan Hunting Word ( Huwo ) serta memotivasi siswa untuk lebih bersemangat. Pelaksanaan kegiatan inti adalah pembelajaran dengan teknik permainan Huwo. Kegiatan ini berlangsung 60 menit. Proses pembelajaran di akhiri dengan kegiatan membuat kesimpulan dan melakukan refleksi.

\section{Siklus II pertemuan kedua}

Pertemuan kedua pada siklus II ini dilaksanakan pada hari Senin, 30 April 2018. Kegiatan ini diawali dengan ucapan salam dan cek kehadiran serta kesiapan siswa. Setelah menyampaikan tujuan pembelajaran guru mereview materi serta proses pembelajaran yang dilaksanakan pada pertemuan pertama yaitu pembelajaran dengan permainan hunting word. Kegiatan ini berlangsung sekitar 15 menit. Kegiatan inti pada pertemuan ini siswa belajar dalam kelompok dengan teknik peer tutoring. Secara berkelompok siswa mengerjakan tugas dengan materi tenses. Kegiatan diskusi dalam kelompok berlangsung 40 menit. Setelah diskusi kelompok dilanjutkan dengan diskusi kelas yang berlangsung 30 menit. Kegiatan pada pertemuan kedua ini diakhiri dengan membuat kesimpulan dan melakukan apersepsi.

\section{Siklus II pertemua ketiga}

Pertemuan ketiga pada siklus II dilaksanakan pada hari Senin, 7 Mei 2018. Kegiatan ini pada pertemuan ini adalah pemberian post test untuk mengukur pemahaman siswa terhadap materi tenses. Hasil pengamatan /observasi selama proses pembelajaran serta post test pada siklus Siklus II dapat dilihat pada table berikut ini yang dilengkapi dengan hasil observasi dan post test pra siklus dan siklus I.

Tabel 3. Hasil observasi siklus I dan II

\begin{tabular}{|c|c|c|c|c|c|c|c|}
\hline \multirow{2}{*}{ No } & \multirow{2}{*}{ Indikator } & \multicolumn{2}{|c|}{ Pra-Siklus } & \multicolumn{2}{|c|}{ Siklus I } & \multicolumn{2}{|c|}{ Siklus II } \\
\hline & & Jumlah & $\%$ & Jumlah & $\%$ & Jumlah & $\%$ \\
\hline 1 & Tingkat kehadiran & 36 & $100 \%$ & 36 & $\begin{array}{l}100 \\
\%\end{array}$ & 36 & $100 \%$ \\
\hline 2 & $\begin{array}{l}\text { Keaktifan menjawab } \\
\text { pertanyaan guru }\end{array}$ & 6 & $17 \%$ & 15 & $42 \%$ & 33 & $91,7 \%$ \\
\hline 3 & $\begin{array}{l}\text { Keaktifan saat } \\
\text { diskusi kelompok }\end{array}$ & 12 & $33 \%$ & 18 & $50 \%$ & 34 & $94,4 \%$ \\
\hline & $\begin{array}{l}\text { Rata-rata aktivitas } \\
\text { siswa }\end{array}$ & & $50 \%$ & & $64 \%$ & & $95,4 \%$ \\
\hline
\end{tabular}




\begin{tabular}{|c|c|c|c|c|c|c|c|c|}
\hline \multirow{2}{*}{ NO } & \multirow{2}{*}{ Uraian } & \multirow{2}{*}{ Kriteria } & \multicolumn{3}{|c|}{ Pra Siklus } & Siklus I & \multicolumn{2}{|c|}{ Siklus II } \\
\hline & & & Jml & $\%$ & Jml & $\%$ & Jml & $\%$ \\
\hline \multirow[t]{4}{*}{1.} & $\begin{array}{l}\text { Jumlah siswa } \\
\text { yang tuntas }\end{array}$ & $\begin{array}{l}\text { Sangat } \\
\text { baik }\end{array}$ & 0 & 0 & 5 & 13,9 & 12 & 33,3 \\
\hline & $\begin{array}{l}\text { dengan kriteria } \\
\text { sangat baik }\end{array}$ & $(90-100)$ & 5 & 13,9 & 9 & 25 & $\begin{array}{l}1 \\
5\end{array}$ & 41,7 \\
\hline & $\begin{array}{l}\text { Jumlah siswa } \\
\text { yang tuntas }\end{array}$ & $\begin{array}{l}\text { Baik } \\
(83-89)\end{array}$ & 12 & 33,3 & 14 & 38,9 & 7 & 19,4 \\
\hline & $\begin{array}{l}\text { dengan kriteria } \\
\text { baik }\end{array}$ & & 19 & 52,8 & 8 & 22,2 & 2 & 5,6 \\
\hline & $\begin{array}{l}\text { Jumlah siswa } \\
\text { yang tuntas } \\
\text { dengan kriteria } \\
\text { cukup }\end{array}$ & $\begin{array}{l}\text { Cukup } \\
(76-82)\end{array}$ & & & & & & \\
\hline \multirow{2}{*}{4.} & $\begin{array}{l}\text { Jumlah siswa } \\
\text { yang tuntas } \\
\text { dengan kriteria } \\
\text { kurang }\end{array}$ & $\begin{array}{l}\text { Kurang } \\
\leq 76\end{array}$ & & & & & & \\
\hline & $\begin{array}{l}\text { Jumlah } \\
\text { Tuntas }\end{array}$ & Nilai $\geq 76$ & 17 & & & 28 & & $94 \%$ \\
\hline
\end{tabular}

Dari table 3 di atas dapat dikatakan bahwa telah terjadi peningkatan yang luar biasa terkait dengan aktivitas siswa dalam proses pembelajaran . Hal tersebut nampak pada peningkatan jumlah siswa yang aktif menjawab pertanyaan guru saat diskusi pembahasan soal-soal yang mana pada siklus I ada 15 siswa dan menjadi 33 siswa pada siklus II. Begitu pula saat diskusi kelompok, pada saat tindakan siklus I hanya ada 18 siswa yang aktif dalam berdiskusi dan itupun didominasi oleh siswa dari kelompok siswa belajar cepat ( pandai ), sementara pada siklus II hampir seluruh siswa aktif dalam berdiskusi.

Sementara hasil tes akhir siklus II pada tabel 2 menunjukkan bahwa ada $12(33,3 \%)$ siswa yang tuntas dengan kriteria sangat baik, ada 15 (41,7\%) siswa yang tuntas dengan kriteria baik serta 7 ( 19,4\%) siswa tuntas dengan kriteria cukup. Sementara yang tidak tuntas hanya 2 siswa ( 5,6\%). Berdasarkan data di atas diketahui bahwa persentase jumlah siswa yang mendapatkan nilai $\geq 76$ adalah $94,4 \%$. Hal itu berarti bahwa hasil belajar siswa pada siklus II telah memenuhi standart ketuntasan klasikal yaitu $85 \%$.

\section{Pembahasan}

\section{Peningkatan Aktivitas Siswa}

Hal yang diamati dalam pembelajaran materi tenses dengan menerapkan Huwo Game dan peer tutoring ini adalah aktivitas siswa kelas X MIPA 8. Menurut hasil observasi sebelum tindakan, aktivitas siswa kelas tersebut sangat rendah dalam pembelajaran bahasa Inggris khususnya pada materi tenses. Oleh karena itu pembelajaran dengan teknik permainan dan peer tutoring diterapkan untuk meningkatkan antusiasme dan aktivitas siswa dalam proses pembelajaran. Dengan teknik permainan siswa akan terlibat dalam proses pembelajaran secara antusias, aktif serta rilek. Belajar sambil bermain membuat siswa terhindar dari stress. Sedangkan dengan peer tutoring akan membuat siswa lebih mudah memahami materi yang dipelajari. Belajar pada prinsipnya adalah berbuat, berkegiatan dan mengubah tingkat laku. 
Tidak ada belajar kalau tidak ada aktivitas. Itulah sebabnya aktivitas merupakan prinsip penting dalam interaksi belajar mengajar. Hal ini yang mendasari peneliti untuk mengamati aktivitas siswa.

Berdasarkan data analisis hasil observasi siswa selama pelaksanaan tindakan siklus I dan II ditemukan adanya peningkatan aktivitas siswa yang sangat signifikan dalam proses pembelajaran tenses dengan menerapkan teknik Huwo Game dan Peer Tutoring. Peningkatan aktivitas siswa dalam proses pembelajaran dapat dilihat pada tabel 3. Berdasarkan data hasil observasi yang dapat dilihat pada tabel 3 di atas diketahui bahwa sebelum dilakukan tindakan siklu I, aktivitas siswa dalam proses pembelajaran dengan materi tenses sangat rendah. Hal itu ditunjukkan dengan rendahnya jumlah siswa yang aktif dalam proses pembelajaran yaitu siswa yang aktif menjawab pertanyaan guru hanya $17 \%$ dan saat diskusi kelompok hanya $33 \%$ meski tingkat kehadirannya tinggi yaitu 100\%. Setelah diterapkan teknik Huwo Game dan peer tutoring, aktivitas siswa dalam proses pembelajaran meningkat sangat signifikan. Jumlah siswa yang aktif menjawab pertanyaan guru saat berdiskusi meningkat menjadi $42 \%$ dibanding sebelum tindakan siklus I dan menjadi $91,7 \%$ pada siklus II sedangkan jumlah siswa yang aktif berdiskusi meningkat menjadi $50 \%$ pada siklus I dan meningkat signifikan pada siklus II yaitu 94,4\%. Persentase kehadiran siswa stabil yaitu $100 \%$ pada siklus I dan II. Indikator-indikator tersebut merupakan cerminan bahwa antusiasme dan partisipasi siswa dalam pembelajaran sangat tinggi. Tidak ada lagi siswa yang malas atau ogah-ogahan dalam belajar.

Deskripsi data di atas menunjukkan bahwa belajar yang dikemas dalam bentuk permainan dapat meningkatkan antusiasme dan motivasi siswa untuk aktif berpartisipasi dalam proses pembelajaran. Hal itu sejalan dengan yang disampaikan oleh Adenan ( 1983:2) bahwa teka-teki dan permainan merupakan aktifitas yang penuh motivasi yang benar-benar dapat membuat siswa tertarik untuk belajar bahasa. Permainan membuat siswa merasa santai dalam pelajar. Selain itu permainan dapat mencegah rasa bosan. Sementara belajar secara berkelompok dengan peer tutoring membuat siswa percaya diri karena tingkat pemahaman siswa terhadap materi yang dipelajari tinggi.

\section{Peningkatan hasil belajar siswa}

Hal yang diteliti selain aktivitas siswa adalah hasil belajar siswa. Untuk mengetahui peningkatan hasil belajar siswa, peneliti menganalisis data dari hasil post test berupa tes tulis pada setiap akhir siklus I dan II.

Dibandingkan dengan sebelum pelaksanaan tindakan, aktivitas siswa pada proses pembelajaran pada siklus I meningkat signifikan, begitu juga dengan hasil belajar siswa. Akan tetapi ketuntasan hasil belajar pada siklus I belum memenuhi standar ketuntasan klasikal karena hanya mencapai $72,2 \%$. Ada peningkatan sebesar $25 \%$ siswa yang tuntas dibanding dengan sebelum siklus I. Faktor yang menyebabkan belum maksimalnya ketuntasan hasil belajar siswa pada siklus I adalah keterlibatan siswa dalam diskusi kelompok belum optimal. Siswa yang katagori low ( lambat) masih malu-malu dan enggan bertanya. Mereka cenderung pasif dan menjadi "penumpang gelap" ( hitch-hike), pasrah asal namanya tercantum dalam kelompok. Sementara siswa yang katagori high ( cepat ) masih ragu-ragu dan nampak kurang percaya diri menjelaskan dan membantu temannya yang kesulitan dalam memahami materi. Padahal esensi dari belajar dalam kelompok ( cooperative learning) adalah tanggung jawab individu sekaligus kelompok, sehingga dalam diri siswa terbentuk sikap kebergantungan positif ( postive independence) yang menjadikan kerja kelompok berjalan optimal. Keadaan ini mendorong siswa-dalam kelompoknya-belajar, bekerja, dan bertanggung jawab dengan sungguh-sungguh( we are in this tohether, sink or swam) sampai dengan selesainya tugastugas individu dan kelompoknya ( Johnson dalam Barokah (1998). 
Dalam kondisi pembelajaran yang seperti itu , guru berperan sangat kompleks. Selain sebagai fasilitator, guru juga berperan sebagai manager dan konsultan dalam memberdayakan kerja kelompok siswa. Ada lima hal peranan utama guru ( Johnson dalam Barokah 1998 ) dalam belajar secara kelompok : (1) menyampaikan tujuan pembelajaran dengan sejelasjelasnya; (2) membentuk kelompok-kelompok kecil dengan menempatkan siswa secara heterogin;(3) menyampaikan tugas-tugas yang harus dikerjakan siswa dengan sejelas-jelasnya; (4) memantau efektifitas kerja kelompok dan menyediakan bantuan kepada siswa ( misalnya: menjawab pertanyaan) untuk memaksimalkan kerja kelompok; ( 5) mengevaluasi hasil kerja siswa dan membantu siswa berdiskusi tentang manfaat kerja kelompok.

Siklus II dilaksanakan berdasarkan refleksi siklus I . Guru memberikan penjelasan sejelas-jelasnya tujuan dan tugas yang harus dikerjakan siswa baik pada saat pelaksanaan pembelajaran dengan teknik permainan maupun pada saat peer tutoring. Guru memotivasi siswa untuk aktif berperan dalam diskusi kelompok dan tidak segan atau malu bertanya kepada temannya yang lebih memahami materi. Guru juga mendampingi secara intensif pada saat siswa kerja dalam kelompok.

Dari hasil analis ketuntasan belajar diketahui bahwa ketuntasan hasil belajar siswa secara klasikal pada siklus II mencapai $94 \%$. Hal itu berarti ketuntasan hasil belajar siswa mengalami peningkatan sangat signifikan dibanding pada siklus I. Terjadi kepeningkatan sebesar 21,8\% dari siklus I. Dengan ketuntasan klasikal sebesar $94 \%$ berarti ketuntasan hasil belajar siswa secara klasikal sudah mencapai target yang ingin dicapai yaitu $\geq 85 \%$.

Hasil penelitian ditemukan bahwa penerapan tehnik Huwo Game dikombinasi dengan Peer Tutoring dalam pembelajaran tenses memberi nilai yang sangat positif terhadap aktivitas siswa dalam proses pembelajaran . Peningkatan aktivitas siswa sebanding dengan peningkatan hasil belajar siswa. Tingginya aktivitas siswa dalam proses pembelajaran berdampak pada tingginya ketuntasan hasil belajar siswa.

\section{KESIMPULAN}

Berdasarkan hasil penelitian dan pembahasan yang telah diuraikan, maka dapat disimpulkan bahwa penerapan Huwo Game dan Peer Tutoring dalam pembelajaran tenses dapat meningkatkan keaktifan siswa kelas X MIPA 8 SMAN 2 Jember tahun pelajaran 2017 2018. Hal itu ditunjukkan dengan naiknya persentase jumlah siswa yang aktif dalam proses pembelajaran baik dalam menjawab pertanyaan guru maupun dalam diskusi kelompok. Setelah tindakan Siklus I dan II jumlah siswa yang aktif menjawab pertanyaan guru maupun dalam diskusi kelompok mencapai lebih dari $75 \%$ dari jumlah siswa yang hadir. Penerapan Huwo Game dan Peer Tutoring dalam pembelajaran tenses pada siswa kelas X MIPA 8 SMAN 2 Jember tahun pelajaran 2017 - 2018 juga dapat meningkatkan hasil belajar siswa, yang ditunjukkan dengan peningkatan persentase ketuntasan klasikal yaitu mengalami peningkatan dari pra siklus 47,2 \%, setelah siklus I menjadi 72,2 \% dan menjadi $94 \%$ setelah siklus II. Sehubungan dengan adanya temuan-temuan dalam penelitian ini, peneliti memberikan saran kepada para guru khususnya guru Bahasa Inggris untuk sebaiknya mencoba menerapkan tehnik Huwo Game dan Peer Tutoring untuk meningkatkan aktifitas dan partisipasi siswa dalam proses pembelajaran sehingga hasil belajar siswa menjadi meningkat pula. 


\section{DAFTAR PUSTAKA}

Adenan. (1983). Puzzles and Games for Students of FKIP. Yokyakarta Kanesius

Ali, M. (1998). Strategi Penelitian Pendidikan. Bandung. Angkasa

Allyn and Bacon. (1996). Active Learning 101 Strategies to Teach Any Subject. Mel Silberman Temple University

Arikunto. (2002). Dasar-Dasar Evaluasi Pendidikan (Edisi Revisi). Jakarta : Bumi Aksara.

Arikunto, Suharsimi. (2010). Penelitian Tindakan Kelas :PT.Bumi Aksara

Baruch and Woon. (1978). A handbook of Communication Activities for Young Learners. Singapore: Seameo Regional Language Center

Brown, H. Douglas. (2007).Teaching by Principles: An Interactive Approach to Language Pedagogy. San Fransisco: Pearson Longman.

Depdikas . (2016) .Peraturan Menteri Pendidikan dan Kebudayaan Nomor 21 tahun 2016 Tentang Standar Isi Pendidikan Dasar dan Menengah.Jakarta : Depdiknas

Hughes, A. (1996). Testing for Language Teachers. New York: Cambridge University Press

Lie, Anita. (2002). Cooperative Learning : Mempraktekkan Cooperative Learning di Ruang ruang Kelas .Jakarta. PT. Gramedia

Murphy ,Murphy. (1994). English Grammar in Use. A reference and pactice book for intermediate studens. Cambridge University Pressd

Manser.M.H. (1992). Oxford Learners' Dictionary. Oxford: Oxford University Press

Rohmah, Zuliati . (2016). Teaching English Joyfully. Malang :BS Press

Slameto. (2008).Belajar dan Faktor-Faktor yang Mempengaruhinya: Rineka Cipta

Widiati, U.\& Cahyono.B.Y. (2006). The Teaching of English Grammar in the Indonesian Context: The State of Art. AJournal of Culture, English Language Teaching \& Literature.

Widdowson, H. G. (1978). Teaching Language as Communication. Oxford University Press. 